No 4078

Studia nad Autorytaryzmem i Totalitaryzmem 43, nr 4 Wrocław 2021

https://doi.org/10.19195/2300-7249.43.4.40

KAZIMIERZ J. LEŻAK

ORCID: 0000-0003-0038-0245

Uniwersytet Wrocławski

kazimierz.lezak@uwr.edu.pl

\title{
Czy zmierzamy w stronę autorytarnego sądowego procesu karnego?
}

Słowa kluczowe: autorytaryzm, postępowanie karne, władza sądownicza.

\author{
ARE WE ON A PATH TOWARDS AN AUTHORITARIAN CRIMINAL \\ JUSTICE PROCESS?
}

\begin{abstract}
The article discusses recent changes in the Polish Code of Criminal Procedure in the sphere of the prosecutor's right to oppose decisions made by a court during the trial. The purpose of the article is to show the public prosecutor's increasing interference in the course of criminal proceedings, which, as a result, makes it possible to take control over the course and outcome of specific criminal proceedings.
\end{abstract}

Keywords: authoritarianism, criminal procedure, judicial authorities, criminal justice system.

\section{I}

Autorytaryzm definiuje się w literaturze jako system polityczny o ograniczonym, zwolnionym z odpowiedzialności przed społeczeństwem pluralizmie politycznym, pozbawiony dopracowanej głównej ideologii, ale z wyraźnymi cechami mentalnymi, wolny (z wyjątkiem pewnych okresów swego rozwoju) od ekstensywnej i intensywnej mobilizacji politycznej. Ponadto w takim ustroju przywódca 
lub niekiedy mała grupa przywódcza dysponuje władzą o słabo określonych formalnych granicach, które jednakże w istocie łatwo przewidzieć ${ }^{1}$.

System autorytarny charakteryzuje się między innymi tym, że rządzący starają się kontrolować jedynie struktury państwowe, nie aspirując przy tym do sprawowania absolutnej wszechwładzy nad społeczeństwem. Autorytarni politycy zwykle zadowalają się samym rządzeniem i ich celem jest wyłącznie władza w sensie politycznym ${ }^{2}$. Co więcej, jej cechą jest to, że nie poddaje się kontroli członków zbiorowości, w obrębie której jest ona sprawowana ${ }^{3}$.

Chęć ciągłego utrzymania się autorytarnych polityków u sterów państwa w połączeniu z ich brakiem odpowiedzialności przed społeczeństwem bazuje na określonych rozwiązaniach prawno-ustrojowych lub prawno-instytucjonalnych.

\section{II}

Badania nad autorytaryzmem (i totalitaryzmem) nieustannie pozostają $\mathrm{w}$ orbicie zainteresowań nauki ${ }^{4}$. Problematyka autorytaryzmu poddawana jest analizie naukowej przede wszystkim w odniesieniu do zagadnień związanych z państwem, jego ustrojem i systemem rządów ${ }^{5}$. Stąd też autorytaryzm jest domeną nauki o polityce oraz nauki o państwie. Nie oznacza to jednak, że tego typu kwestie są poza kręgiem zainteresowań prawników. Autorytaryzm pozostaje przedmiotem analiz w nauce prawa polskiego. Rzecz jednak w tym, że badania na tym polu obejmują zazwyczaj konkretne, wycinkowe zagadnienia prawne ${ }^{6}$ lub też mają historycznoprawny charakter ${ }^{7}$, co należało uznać za uzasadnione podejście $\mathrm{z}$ uwagi na rozwiązania prawno-ustrojowe, jakie obowiązywały w Polsce do 1989 roku.

W obliczu ostatnich zmian w prawie, dokonywanych po 2015 roku, pojawiły się jednak, zarówno w dyskursie politycznym ${ }^{8}$, jak i prawnym, wypowiedzi odnoszące się do aktualnej sytuacji prawno-ustrojowej Polski, w których zauważano,

1 J.J. Linz, Totalitaryzm i autorytaryzm, [w:] Władza i społeczeństwo. Antologia tekstów z zakresu socjologii polityki, wyb. i oprac. J. Szczupaczyński, Warszawa 1995, s. 310.

2 M. Bankowicz, Autorytaryzm i totalitaryzm - analiza porównawcza, [w:] Totalitaryzmy XX wieku. Idee, instytucje, interpretacje, red. W. Kozub-Ciembroniewicz, Kraków 2010, s. 26.

3 Ibidem, s. 26.

${ }^{4}$ Najlepszym przykładem ciągłego zainteresowania problematyką autorytaryzmu i totalitaryzmu jest wydawane przez Uniwersytet Wrocławski od 1974 roku czasopismo „Studia nad Autorytaryzmem i Totalitaryzmem” (do 2012 roku „Studia nad Faszyzmem i Zbrodniami Hitlerowskimi”).

5 Zob. przykładowo: J. Tomasiewicz, Naprawa czy zniszczenie demokracji? Tendencje autorytarne i profaszystowskie w polskiej myśli politycznej 1921-1935, Katowice 2012.

${ }^{6}$ M. Rojszczak, Nieograniczone programy inwigilacji elektronicznej a koncepcja państwa autorytarnego, „Studia nad Autorytaryzmem i Totalitaryzmem” 42, 2020, nr 2, s. 207 n.

${ }^{7}$ G. Lawnikowicz, W poszukiwaniu istoty nowego autorytarnego porządku. Antoniego Peretiatkowicza koncepcja cezaryzmu demokratycznego, „Studia nad Autorytaryzmem i Totalitaryzmem" 42, 2020, nr 2, s. 163 n.

${ }^{8}$ M. Gdula, Nowy autorytaryzm, Warszawa 2018. 
że skutkiem tych przeobrażeń jest odchodzenie od rządów demokratycznych w kierunku ustroju autorytarnego 9 .

Autorytaryzm charakteryzują cztery fundamentalne cechy. Po pierwsze, wyróżnia go ograniczony pluralizm polityczny. Ustrój ten dopuszcza pewną różnorodność postaw i przekonań politycznych, aczkolwiek ten stan rzeczy jest bardziej tolerowany niż uznawany. Jednak w autorytaryzmie zawsze da się zidentyfikować jakieś niezależne od władzy i stawiające sobie za cel oddziaływanie na politykę grupy. Po drugie, reżimy autorytarne odznaczają się stosunkowo niskim stopniem zideologizowania i widoczny jest w nich brak ideologii państwowej, która kreśliłaby wizję idealnego porządku politycznego. Po trzecie, w systemie tym nie wyraża się postulatu mobilizacji politycznej społeczeństwa; szczególnie jest to zauważalne wówczas, gdy znajduje się on już w fazie stabilizacji. Po czwarte wreszcie, w ustroju autorytarnym władza rządzącej jednostki lub grupy jest $\mathrm{z}$ reguły słabo zdefiniowana $\mathrm{w}$ sensie formalnym, choć zarazem jej granice są łatwe do przewidzenia przez tych, którzy jej podlegają. Ważne tu jest również to, że w aparacie państwowym dominują struktury biurokratyczne, wojskowe, policyjne lub inne, zaś zaplecza politycznego dla rządzących nie tworzy partia masowa ${ }^{10}$.

Wyrażane w dyskursie prawniczym oceny zmian prawa, które pod pozorem poprawienia funkcjonalności, transparentności czy sprawności działania prowadzą do ustroju autorytarnego ${ }^{11}$, dotykają przede wszystkim płaszczyzny instytucjonalnej i bazują na ich globalnej analizie. Najlepiej widać to na przykładzie modyfikacji dotyczących ustroju i struktury Sądu Najwyższego ${ }^{12}$, ustroju sądownictwa powszechnego ${ }^{13}$, ustroju i funkcjonowania Krajowej Rady Sądownictwa ${ }^{14}$ czy „reformy” sądownictwa dyscyplinarnego sędziów ${ }^{15}$ w powiązaniu

9 Zob. A. Bosiacki, Pomiędzy państwem prawnym a autorytaryzmem. Z polskich rozważań nad poszukiwaniem optymalnego ustroju państwa po odzyskaniu niepodległości w III Rzeczypospolitej, „Studia nad Autorytaryzmem i Totalitaryzmem” 38, 2016, nr 4, s. 103; A. Bodnar, Polska to już kraj konkurencyjnego autorytaryzmu. Obudźmy się - wykład RPO Adama Bodnara w Klubie Staromiejskim, Biuro Rzecznika Praw Obywatelskich, 20 kwietnia 2021 roku, https://www.rpo.gov.pl/ $\mathrm{pl} /$ content/polska-konkurencyjny-autorytaryzm-obudzmy-sie-wyklad-rpo-adama-bodnara (dostęp: 18.12.2021).

10 J.J. Linz, op. cit., s. 310.

11 Zob. przykładowo uzasadnienie projektu ustawy o Sadzie Najwyższym, druk sejmowy nr 2003 z 26 września 2017 roku, https://orka.sejm.gov.p1/Druki8ka.nsf/0/5AB89A44A6408C3C C12581D800339FED/\%24File/2003.pdf (dostęp: 18.12.2021).

12 Ustawa z 8 grudnia 2017 roku o Sądzie Najwyższym, Dz.U. z 2021 r., poz. 154 (tekst jedn.) z późn. zm.

13 Ustawa z 27 lipca 2001 roku - Prawo o ustroju sądów powszechnych, Dz.U. z 2020 r., poz. 2072 (tekst jedn.) z późn. zm.

14 Ustawa z 12 maja 2011 roku o Krajowej Radzie Sądownictwa, Dz.U. z 2021 r., poz. 269 (tekst jedn.) z późn. zm.

15 Zob. art. 72-76 ustawy z 8 grudnia 2017 roku o Sądzie Najwyższym, Dz.U. z 2021 r., poz. 154 (tekst jedn.) z późn. zm. oraz art. 107-133a ustawy z 27 lipca 2001 roku - Prawo o ustroju sądów powszechnych, Dz.U. z 2020 r., poz. 2072 (tekst jedn.) z późn. zm. 
z symptomatycznymi słowami ówczesnego posła na Sejm Rzeczypospolitej Polskiej ${ }^{16}$ Stanisława Piotrowicza, które ten wypowiedział 22 listopada 2017 roku podczas 52. posiedzenia Sejmu VIII kadencji:

[...] Ale w reformie nie chodzi tylko o szybkość postępowania, bo o to zatroszczymy się przy kolejnych projektach ustaw, które będą wiązały się z procedurą. W tej chwili zmierzamy do tego, ażeby przeprowadzić reformę instytucjonalną tych ważnych dla wymiaru sprawiedliwości instytucji, a więc Krajowej Rady Sądownictwa i Sądu Najwyższego. Chodzi nam nie tylko o zmiany o charakterze strukturalnym, ale również o zmiany o charakterze personalnym. Gdy mówię o zmianach personalnych, chodzi mi o to, żeby doszło do przemiany jakościowej sędziów, którzy będą ludźmi o mentalności służebnej wobec państwa i narodu [wyr. - K.J.L.] ${ }^{17}$.

W przypadku tego rodzaju zmian charakterystyczne jest to, że mają one kompleksowy charakter, zmierzając do nowego ukształtowania danej instytucji, i jednocześnie, gdy są one analizowane w kontekście prawno-ustrojowym, oceniane są jako charakterystyczne dla ustroju autorytarnego.

Kwestię zmian instytucjonalnych (globalnych) w obrębie wskazanych wyżej instytucji, ich celu, nakierowanego na podporządkowanie władzy sądowniczej pozostałym dwóm władzom (ustrój sądownictwa, procedura nominacji sędziów, kształt Krajowej Rady Sądownictwa), oraz ich wpływu na niezależność sądownictwa i niezawisłość sędziów, a co za tym idzie, umożliwienia ingerencji w treść indywidualnych rozstrzygnięć sądowych (kompetencje Sądu Najwyższego, ustrój i podstawy odpowiedzialności dyscyplinarnej), charakteryzującego ustrój autorytarny, omówiłem w innym miejscu ${ }^{18}$.

\section{III}

Po 2015 roku można dostrzec też innego rodzaju przeobrażenia prawa. Mowa tu o zmianach w poszczególnych jego gałęziach, przy czym ustawodawca jest szczególnie zainteresowany problematyką prawa karnego i procesów w tym zakresie. Choć motyw, czy też deklarowany cel, reform pozostaje ten sam, to jest konieczność usprawnienia bądź naprawy określonych instytucji prawnych lub procedur, to ich funkcja sprowadza się do uzyskania wpływu na realizację funkcji sądzenia ${ }^{19}$, przejawiającej się między innymi w sposobie postępowania, a nawet w treści orzeczeń wydawanych w toku postępowania karnego. Szczególnie jest to

16 Obecnie, od 5 grudnia 2019 roku, sędziego Trybunału Konstytucyjnego.

17 Sprawozdanie stenograficzne z 52. posiedzenia Sejmu Rzeczypospolitej Polskiej w dniu 22 listopada 2017 roku, Warszawa 2017, s. 130.

18 Zob. K.J. Leżak, Sędzia wobec nowego prawa karnego procesowego, [w:] Norma postępowania karnego. Sędzia wobec zmian prawa karnego procesowego, red. J. Skorupka, K.J. Leżak, Kraków 2018, s. 127 n.

19 Jako funkcję sądzenia rozumiem za Jerzym Skorupką jedną z ról procesowych w trójpodmiotowej konstrukcji postępowania karnego, polegającą na rozpoznaniu sprawy w procesie kar- 
widoczne zarówno w nowelizacji przepisów karnomaterialnych, jak też w zmianach dotyczących procedowania w sprawach karnych. Pozornie modyfikacje te mają charakter wycinkowy, „punktowy”, można rzec, że niezauważalny, ponieważ „same w sobie” są neutralne systemowo, pozostając bez wpływu na ocenę kierunku modyfikacji prawa w aspekcie globalnym, jako element reform zmierzających ku systemowi autorytarnemu.

Dostrzeżenie wzajemnego powiązania i skutków wskazanego powyżej rodzaju przeobrażeń $\mathrm{w}$ zakresie procedury karnej z perspektywy prawidłowości realizacji przez sądy funkcji sądzenia, będącej podstawowym atrybutem władzy sądowniczej, skłania do postawienia trudnego i złożonego, ale jednocześnie niepokojącego, pytania, czy charakter owych zmian prowadzi do nadania tej gałęzi prawa cech autorytarnych?

\section{IV}

Przedmiotem analizy podjętej w niniejszym opracowaniu jest polski sądowy proces karny oparty na przepisach k.p.k. z 1997 roku$^{20}$. Przy tym chodzi tu o kompleksowe omówienie (diagnozę) sądowego stosowania prawa karnego procesowego, nie zaś jego poszczególnych regulacji czy instytucji procesowych. Ograniczenie przeglądu zmian w procedurze karnej do postępowań sądowych wynika z faktu, że to sąd jako reprezentant trzeciej władzy, odrębnej i niezależnej od pozostałych władz, władczo i prawomocnie przesądza o odpowiedzialności karnej oskarżonego ${ }^{21}$, co stanowi zasadniczą postać realizacji funkcji orzekania (rozstrzygania, sądzenia) na etapie jurysdykcyjnym. Jedną z cech autorytaryzmu jest zaś to, że w ustroju tym dąży się do kontroli nad działalnością wszystkich organów państwa, niezależnie od tego, do której z podzielonych władz należą, a w konsekwencji do zwolnienia rządzących z odpowiedzialności względem społeczeństwa, w tym z odpowiedzialności prawnej, a zatem także i karnej. Wpływ na przebieg postępowania czy treść sądowych decyzji w tym zakresie stanowi zatem ważny element sprawowania władzy autorytarnej.

Celem artykułu jest wykazanie, że kolejne, pozornie neutralne zmiany o punktowym charakterze, dokonywane systematycznie i co jakiś czas przy okazji nowelizacji innych przepisów, pod hasłem usprawniania czy poprawy określonych instytucji lub procedur, układają się w pewien system, umożliwiający kontrolę nad przebiegiem i wynikiem konkretnego procesu karnego.

nym i rozstrzygnięciu o jego przedmiocie, czyli kwestii odpowiedzialności prawnej oskarżonego —idem, [w:] Proces karny, red. J. Skorupka, Warszawa 2017, s. 86.

20 Dz.U. z 2021 r. poz. 534 z późn. zm.

21 Trzeba jednak zauważyć, że już w toku postepowania przygotowawczego można rozstrzygnąć kwestię odpowiedzialności karnej w określonym kierunku, na przykład poprzez umorzenie postępowania, a co za tym idzie, zaniechanie ścigania i karania sprawcy. 
Przykładem tego rodzaju dążeń są modyfikacje w zakresie znanej i ugruntowanej $\mathrm{w}$ procedurze karnej konstrukcji prawnej22 ${ }^{22}$ sprzeciwiania się prokuratora (dalej alternatywnie: sprzeciw prokuratora). Z perspektywy dogmatycznej w literaturze wskazuje się, że sprzeciw dotyczy określonego sposobu rozpoznania danej sprawy, która nie jest środkiem zaskarżenia, a pewnego rodzaju oświadczeniem, które ma na celu wywołanie skutku w postaci zablokowania podjętej przez sąd decyzji procesowej ${ }^{23}$.

\section{V}

Pierwotnie w przepisach k.p.k. konstrukcja sprzeciwu prokuratora występowała:

- w związku z koniecznością uzasadnienia postanowienia o dopuszczeniu dowodu (art. $98 \S 3$ k.p.k.);

— w związku z koniecznością odebrania przyrzeczenia od świadka (art. 187 $\S 3$ k.p.k.);

- w odniesieniu do formy rozstrzygnięcia o wniosku dowodowym strony (art. 368 k.p.k.);

- w zakresie możliwości prowadzenia rozprawy odroczonej w dalszym ciągu (art. $404 \S 2$ k.p.k.).

W 2003 roku $^{24}$ ustawodawca wprowadził ponadto konstrukcję sprzeciwu prokuratora do instytucji wydania wyroku skazującego bez przeprowadzania postępowania dowodowego (art. 387 § 2 k.p.k.) oraz w odniesieniu do możliwości odczytania protokołów przesłuchania świadków i oskarżonych, sporządzonych $\mathrm{w}$ postępowaniu przygotowawczym lub przed sądem albo $\mathrm{w}$ innym postępowaniu przewidzianym przez ustawę, gdy bezpośrednie przeprowadzenie dowodu nie jest niezbędne (art. 392 § 1 k.p.k.). Jednocześnie usunięto konstrukcję sprzeciwienia się prokuratora $\mathrm{w}$ odniesieniu do możliwości prowadzenia rozprawy odroczonej w dalszym ciągu (art. 404 § 2 k.p.k.). Z kolei w 2015 roku $^{25}$ wprowadzono sprzeciw prokuratora $\mathrm{w}$ nowej instytucji wniosku oskarżonego o skazanie go bez przeprowadzania rozprawy (art. 338a k.p.k. w zw. z art. 343a § 2 k.p.k.).

Uchwalane w okresie do 2016 roku zmiany w przepisach k.p.k., polegające między innymi na wprowadzeniu konstrukcji sprzeciwu prokuratora do

${ }^{22} \mathrm{Na}$ temat pojęcia konstrukcji prawnej i elementów odróżniających to pojęcie od terminu instytucji prawnej zob. Z. Ziembiński, Szkice z metodologii szczegółowych nauk prawnych, Warszawa-Poznań 1983, s. 88, 93-94.

23 J. Skorupka, [w:] Proces..., s. 739.

24 Ustawa z 10 stycznia 2003 roku o zmianie ustawy — kodeks postępowania karnego, ustawy - Przepisy wprowadzające Kodeks postępowania karnego, ustawy o świadku koronnym oraz ustawy o ochronie informacji niejawnych (Dz.U. z 2003 r. Nr 17, poz. 155).

25 Ustawa z 27 września 2013 roku o zmianie ustawy — kodeks postępowania karnego oraz niektórych innych ustaw (Dz.U. z 2013 r., poz. 1247 z późn. zm.). 
wskazanych powyżej instytucji procesowych nie wzbudzały niepokoju zarówno w doktrynie, jak i w orzecznictwie sądowym. Poza spostrzeżeniem, że chodzi tu o trzy takie przypadki w ciągu 18 lat, trzeba wskazać, że wprowadzenie do art. 387 $\S 2$ k.p.k. i art. 392 § a k.p.k. konstrukcji sprzeciwu prokuratora było wynikiem krytycznych uwag dotyczących funkcjonującej dotąd konstrukcji zgody stron, $\mathrm{w}$ tym prokuratora ${ }^{26}$, a co za tym idzie, miało ono na celu usprawnienie procedowania $\mathrm{w}$ ramach instytucji, których dotyczyły owe sprzeciwy. Z kolei sprzeciw prokuratora uregulowany w art. 343a $\S 2$ k.p.k. stanowił element nowej instytucji procesowej, określonej $\mathrm{w}$ art. 338a k.p.k., bazującej na instytucji dobrowolnego poddania się karze uregulowanej w art. 335 k.p.k., uwzgledniającej podmiot składający wniosek, którym jest oskarżony, nie zaś prokurator. Stąd też oskarżyciel - dla równowagi - otrzymał prawo sprzeciwienia się wnioskowi oskarżonego, tak jak podsądny ma prawo sprzeciwić się wnioskowi prokuratora, składanemu w trybie art. 335 k.p.k.

Zgoła odmienne spostrzeżenia należy poczynić, analizując wprowadzane w ramach kolejnych nowelizacji k.p.k. konstrukcje sprzeciwu prokuratora. W 2016 roku $^{27}$ ustawodawca wprowadził konstrukcję sprzeciwu prokuratora do instytucji jawności rozprawy głównej. Zgodnie z nowym brzmieniem art. 360 k.p.k., regulującym przesłanki wyłączenia jawności rozprawy głównej na wniosek, w $\S 2$ tego przepisu wskazano, że jeżeli oskarżyciel sprzeciwi się wyłączeniu jawności, rozprawa odbywa się w trybie jawnym.

Następnie, w 2019 roku $^{28}$, ustawodawca wprowadził konstrukcję sprzeciwienia się prokuratora do dwóch kolejnych instytucji procesowych. Po pierwsze, w sytuacji gdy pokrzywdzony cofa wniosek o ściganie po rozpoczęciu przewodu sądowego, w znowelizowanej treści art. $12 \S 3$ k.p.k. zastrzeżono, że w sprawach, w których akt oskarżenia wniósł oskarżyciel publiczny, cofnięcie wniosku po rozpoczęciu przewodu sądowego jest skuteczne, jeżeli nie sprzeciwi się temu obecny na rozprawie lub posiedzeniu oskarżyciel publiczny. Po drugie, jeżeli sąd, rozstrzygając na podstawie przepisu art. $257 \S 2$ k.p.k o dalszym stosowaniu tymczasowego aresztowania, postanowi, że środek ten ulegnie zmianie pod warunkiem złożenia — nie później niż w wyznaczonym terminie — określonego poręczenia majątkowego, to zgodnie $\mathrm{z}$ treścią dodanego $\S 3$ wskazanego przepisu, jeżeli prokurator oświadczy — najpóźniej w trakcie posiedzenia po ogłoszeniu postanowienia przez sąd - że sprzeciwia się zmianie środka zapobiegawczego,

${ }^{26}$ Zob. Kodeks postępowania karnego, t. 2. Komentarz do artykułów 297-467, red. P. Hofmański, Warszawa 2011, s. 525-526, 557.

27 Ustawa z 10 czerwca 2016 roku o zmianie ustawy — kodeks postępowania karnego, ustawy o zawodach lekarza i lekarza dentysty oraz ustawy o prawach pacjenta i Rzeczniku Praw Pacjenta (Dz.U. z 2016 r. poz. 1070).

28 Ustawa z 19 lipca 2019 roku o zmianie ustawy — kodeks postępowania karnego oraz niektórych innych ustaw (Dz.U. z 2019 r. poz. 1694). 
postanowienie to, w zakresie dotyczącym zamiany tymczasowego aresztowania na poręczenie majątkowe, staje się wykonalne $\mathrm{z}$ dniem uprawomocnienia.

W końcu w 2021 roku $^{29}$, nowelizując instytucję listu żelaznego, zastrzeżono, że w postępowaniu przygotowawczym może on być wydany na wniosek prokuratora albo przy braku jego sprzeciwu (art. $281 \S 2$ k.p.k.).

\section{VI}

Mając na uwadze skutki oświadczenia prokuratora wyrażającego sprzeciw w procesie karnym, sprowadzające się do zablokowania decyzji procesowej podjętej przez sąd, trzeba stwierdzić, że konstrukcja sprzeciwienia przekłada się na sposób prowadzenia postępowania czy treści decyzji procesowej.

Prima facie przytoczone powyżej zmiany w k.p.k., polegające na wprowadzeniu konstrukcji sprzeciwu prokuratora w kolejnych instytucjach procesowych, stanowią wyraz dopuszczalnej ustrojowo kompetencji władzy ustawodawczej do kształtowania rozwiązań w obrębie procedury karnej, mających na celu usprawnienie przebiegu poszczególnych procesów karnych, a ogólnie rzecz ujmując, zapewnienie rzetelności procesu.

Rzecz jednak w tym, że to, co niedostrzegalne na płaszczyźnie normatywnej, odnoszącej się do poszczególnych przepisów, ujawnia się dopiero po przeprowadzeniu odpowiedniej analizy dogmatycznej, uwzględniającej całokształt obowiązujących regulacji, w tym tych kształtujących standardy konstytucyjny i konwencyjny. Problematyczność wskazanych powyżej zmian normatywnych, omawianych w kontekście tytułowego pytania, staje się najlepiej widoczna, gdy przeanalizuje się je w kontekście wypracowanego w doktrynie procesu karnego pojęcia i rodzajów funkcji procesowych.

W literaturze karnoprocesowej wskazuje się, że przejawy działalności procesowej podmiotów procesu karnego można podzielić na określone typy, charakteryzujące zasadnicze kierunki działalności procesowej dla każdego z tych podmiotów w zależności od odgrywanej przez nie w toku postępowania roli. Owe zasadnicze kierunki działalności procesowej, wyznaczone przez procesową rolę odpowiedniego podmiotu procesu karnego, określa się mianem funkcji procesowych $^{30}$. Wśród najważniejszych typów (przejawów) działalności procesowej wyróżnia się działalność uczestników postępowania karnego — organów procesowych, stron procesu oraz ich przedstawicieli procesowych. To z kolei pozwala wyróżnić trzy zasadnicze funkcje procesowe: ścigania, obrony i orzekania (rozstrzygania) $^{31}$. Funkcja ścigania jest realizowana $w$ czynnościach zmierzających

${ }^{29}$ Ustawa z 20 kwietnia 2021 roku o zmianie ustawy — kodeks karny oraz niektórych innych ustaw (Dz.U. z 2021 r., poz. 1023).

30 J. Skorupka, [w:] Proces..., s. 86.

31 Ibidem. 
do ustalenia, ujęcia i pociągnięcia do odpowiedzialności karnej sprawcy przestępstwa. Z kolei funkcja obrony jest nakierowania na ochronę praw oraz interesów oskarżonego (podejrzanego) i zmierza do uzyskania najkorzystniejszego dla niego rozstrzygnięcia. Natomiast funkcja orzekania (rozstrzygania) polega na działalności sprowadzającej się do rozpoznawania spraw w procesie karnym i rozstrzygania o jego przedmiocie, czyli kwestii odpowiedzialności prawnej oskarżonego ${ }^{32}$. Trzeba przy tym zaznaczyć, że w doktrynie procesu karnego funkcja orzekania jest ujmowana w wąskim lub szerokim zakresie. Rozstrzyganie w sensie ścisłym sprowadza się do podjęcia decyzji o odpowiedzialności karnej sprawcy. W szerokim ujęciu obejmuje ono rozpoznanie sprawy, podjęcie decyzji o odpowiedzialności karnej oraz jej wykonanie i w tym przypadku funkcja rozstrzygania odnosi się zarówno do postępowania przygotowawczego, jak i sądowego ${ }^{33}$.

Jeśli uwzględnimy, że funkcja rozstrzygania na etapie postępowania jurysdykcyjnego obejmuje rozpoznanie sprawy (polegające na przeprowadzeniu i ocenie dowodów, ustalenie na ich podstawie faktów, dokonanie ich oceny pod kątem karnoprawnym, czyli określenie kwalifikacji prawnej i wyciągnięcie prawno-karnych konsekwencji z dokonanych ustaleń i ocen), wydanie orzeczenia w przedmiocie odpowiedzialności karnej sprawcy oraz jej wykonanie, to na wskazanym etapie procesu karnego można ją określić jako funkcję sądzenia.

W kontekście konstrukcji sprzeciwiania się prokuratora i jego wpływu na bieg postępowania karnego oraz roli sądu w procesie karnym należy skupić się na relacjach zachodzących miedzy funkcjami ścigania i sądzenia (rozstrzygania).

Funkcję sądzenia w postępowaniu jurysdykcyjnym realizuje sąd, a ponadto również prezes sądu (przewodniczący wydziału, upoważniony sędzia) oraz przewodniczący składu orzekającego. $Z$ kolei funkcja oskarżania przysługuje oskarżycielowi (publicznemu, posiłkowemu, prywatnemu), zaś funkcja obrony — oskarżonemu i jego obrońcy, a także, ze względów gwarancyjnych, oskarżycielowi publicznemu ${ }^{34}$.

$\mathrm{Z}$ analizy powyższego, modelowego ujęcia podmiotów realizujących określone funkcje procesowe jednoznacznie wynika, że komponenty składające się na funkcję sądzenia (ustalenie faktów, ich ocena i określenie konsekwencji karnoprawnych), wyrażające najpełniej zadania z zakresu sprawowania wymiaru sprawiedliwości, realizuje wyłącznie sąd. To ten organ procesowy wykonuje czynności procesowe $\mathrm{w}$ toku postępowania jurysdykcyjnego i podejmuje odpowiednie decyzje procesowe na poszczególnych jego etapach oraz końcową decyzję, rozstrzygającą o odpowiedzialności karnej oskarżonego. A contrario uczestnicy postępowania - a taki status posiadają oskarżony i jego obrońca oraz oskarżyciel (publiczny, posiłkowy, prywatny) — nie mają bezpośredniego wpływu ani na

32 Ibidem, s. 86-90.

33 Ibidem, s. 88.

34 Ibidem, s. 87, 89. 
decyzje sądu dotyczące przebiegu postępowania, ani na treść podejmowanych w sprawie rozstrzygnięć procesowych.

\section{VII}

Powyższe ujęcie modelowe, zakładające realizowanie w pełni funkcji rozstrzygania w postępowaniu jurysdykcyjnym przez sąd, nie jest stosowane w polskim procesie karnym. Wynika to przede wszystkim z konieczności uwzględnienia szeregu wartości realizowanych $\mathrm{w}$ toku postępowania, jak też jego cel i powiązane z nim komponenty, składające się na pozostałe funkcje procesowe, wykonywane przez uczestników postępowania. Tak jak w przypadku zasad procesu karnego również na gruncie realizowanych w nim funkcji procesowych modelowe założenia mają charakter wzorca (funkcji procesowej w ujęciu abstrakcyjnym), który w mniejszym lub większym stopniu jest wcielany w życie w konkretnej, ustawowo określonej procedurze karnej ${ }^{35}$.

Sprzeciw prokuratora, realizującego w procesie sądowym przede wszystkim funkcję ścigania karnego (oskarżania), stanowi wyłom w modelowym (abstrakcyjnym) ujęciu podmiotu wykonującego funkcje sądzenia. Instytucja ta ingeruje bowiem w sposób prowadzenia postępowania, a na skutek omówionych wcześniej zmian w przepisach k.p.k. determinuje także treść decyzji sądowych. O ile jednak jest to nieunikniona konsekwencja ważenia wielu wartości realizowanych w toku procesu karnego i konieczności uwzględnienia szeregu interesów jego uczestników, czego nie można kwestionować, to już można - i trzeba — poddawać ocenie zasadność wprowadzania tego rodzaju ingerencji w realizowanie przez sąd funkcji rozstrzygania w postępowaniu jurysdykcyjnym.

Musimy w tym miejscu zauważyć, że każda ingerencja w sposób prowadzenia postępowania przez sąd (prowadzenia i kierowania rozprawą oraz dopuszczania, przeprowadzania i oceny dowodów, a także ustalania faktów i ich oceny czy też treści wydawanych orzeczeń) przekłada się na ocenę realizacji podstawowego prawa jednostki — do sądu bezstronnego. Bezstronność jest z kolei jednym z najważniejszych elementów standardu rzetelnego procesu ${ }^{36}$. Należy stwierdzić, że gwarancja bezstronnego sądu jest jednym z fundamentalnych praw człowieka, które zapewnia rozstrzyganie przez neutralny podmiot sporów, w których uczestniczy jednostka ${ }^{37}$. Prawa do rozpoznania sprawy przez bezstronny sąd zagwarantowano w art. 6 ust. 1 Konwencji o ochronie praw człowieka i podstawowych

35 Omówienie naczelnych zasad postępowania karnego w ujęciu abstrakcyjnym i konkretnym zob. S. Waltoś, P. Hofmański, Proces karny. Zarys systemu, Warszawa 2018, s. 215, 218 oraz 219 n.

${ }^{36}$ Rzetelny proces karny $w$ orzecznictwie sądów polskich i międzynarodowych, red. P. Wiliński, Warszawa 2009.

37 Zob. T.T. Koncewicz, Sprawiedliwość proceduralna w sądach unijnych. Pierwsze kroki, „Palestra” 2010, nr 11-12, s. 257-258 i przywołana tam literatura. 
wolności z dnia 4 listopada 1950 roku $^{38}$ (dalej: EKPCz). Wymóg bezstronności sądu ma również wymiar konstytucyjny. Konstytucja Rzeczypospolitej Polskiej ${ }^{39}$ w ust. 1 art. 45 gwarantuje każdemu prawo do sprawiedliwego i jawnego rozpatrzenia sprawy bez nieuzasadnionej zwłoki przez właściwy, niezależny, bezstronny i niezawisły sąd.

Przyglądając się przewidzianym w k.p.k. sprzeciwom prokuratora i znaczeniu tej konstrukcji prawnej w ramach poszczególnych instytucji prawnych, trzeba stwierdzić, że pierwotnie ich wprowadzenie do procedury karnej było należycie uzasadnione i nie budziło zastrzeżeń. Zatem w kontradyktoryjnym procesie karnym, prowadzonym na równych prawach, gdzie dowody przeprowadza się na wniosek stron, uzasadnienie postanowienia o dopuszczeniu dowodu, któremu sprzeciwiła się druga strona, wydaje się być konieczne (art. $98 \S 3$ k.p.k.). Dopuszczalność dowodu jest obecnie jedną z kluczowych kwestii zarówno w praktyce orzeczniczej, jak i w doktrynie ${ }^{40}$. Wiedza o motywach dopuszczenia określonego dowodu pozwala w szczególności na kontrolę instancyjną przebiegu danego procesu i wydanego w nim orzeczenia. Również determinowana sprzeciwem strony forma rozstrzygnięcia, to jest wydanie postanowienia, nie budzi zastrzeżeń (art. 368 § 1 k.p.k.). Trzeba bowiem zaznaczyć, że sprzeciw strony, w tym prokuratora, w omawianym zakresie wymusza jedynie określone działanie sądu co do formy i koniecznej treści (nie przesądzając jej), które nie wpływa na bieg procesu czy treść orzeczenia. Również konieczność odebrania przyrzeczenia od świadka, gdy jedna ze stron sprzeciwia się przesłuchaniu go bez przyrzeczenia (art. 187 § 3 k.p.k.), prowadzi do podjęcia przez sąd określonej czynności, niezwiązanej jednak ze sposobem prowadzenia postępowania czy treścią rozstrzygnięcia. Odebranie przyrzeczenia ma zaś to znaczenie, że stanowi jedynie alternatywny warunek odpowiedzialności karnej za przestępstwo składania fałszywych zeznań (art. 233 $\S 2$ k.k.), a jego celem jest li tylko zobowiązanie świadka w uroczystej formule do zeznawania prawdy i podkreślenie w związku z tym wagi prawdziwości jego $z_{z e z n a n}{ }^{41}$. Ponadto uzależnienie możliwości odczytania protokołów przesłuchania świadków i oskarżonych, sporządzonych w postępowaniu przygotowawczym lub przed sądem albo $\mathrm{w}$ innym postępowaniu przewidzianym przez ustawę, gdy bezpośrednie przeprowadzenie dowodu nie jest niezbędne wobec braku sprzeciwu między innymi prokuratora (art. $392 \S 1$ k.p.k.), prowadzi do określonego sposobu procedowania przez sąd. Należy przy tym zauważyć, że sprzeciwienie się przez prokuratora prowadzi do konieczności przesłuchania świadka czy oskarżonego w trakcie rozprawy, co stanowi wyraz zasady bezpośredniości. Tym samym

38 Dz.U. z 1993 r. Nr 61, poz. 284.

39 Dz.U. z 1997 r. Nr 78, poz. 483 z późn. zm.

40 Zob. W. Jasiński, Nielegalnie uzyskane dowody w procesie karnym. W poszukiwaniu optymalnego rozwiazania, Warszawa 2019.

41 D. Gruszecka, [w:] Kodeks postepowania karnego. Komentarz, red. J. Skorupka, Warszawa 2021, s. 463. 
sprzeciw prokuratora $\mathrm{w}$ omawianym zakresie ma ten skutek $\mathrm{w}$ odniesieniu do biegu postępowania, że choć wiąże sąd, to wyłącza jedynie możliwość przeprowadzenia określonych dowodów pośrednio, a przez to wpływa na czas trwania postępowania dowodowego, które i tak musi być zrealizowane podczas rozprawy (czy to pośrednio, czy bezpośrednio).

Nieco inne znaczenie z perspektywy przebiegu procesu ma sprzeciw prokuratora (i drugiej strony procesu) w odniesieniu do możliwości prowadzenia rozprawy odroczonej w dalszym ciągu (art. $404 \S 2$ k.p.k.) oraz w zakresie instytucji wydania wyroku skazującego bez przeprowadzania postępowania dowodowego (art. 387 § 2 k.p.k.), a także instytucji skazania bez przeprowadzania rozprawy na skutek wniosku oskarżonego (art. 338a k.p.k. w związku z art. 343a § 2 k.p.k.).

$\mathrm{W}$ pierwszym $\mathrm{z}$ wymienionych przypadków sprzeciw prokuratora wobec prowadzenia, wyjątkowo, rozprawy odroczonej w dalszym ciągu skutkowało koniecznością przeprowadzenia od nowa rozprawy przez sąd. W doktrynie procesu karnego już od początku obowiązywania k.p.k. podnoszono, że możliwość prowadzenia rozprawy odroczonej w dalszym ciągu została zredukowana do minimum, co często powodowało w praktyce konieczność wielokrotnego prowadzenia rozprawy odroczonej od początku, choć w realiach danej sprawy nie było to uzasadnione, a w konsekwencji przyczyniało się do długotrwałego przewlekania postępowania $^{42}$. Warto zaznaczyć, że ustawodawca, dostrzegając wskazane powyżej mankamenty wprowadzenia konstrukcji sprzeciwienia się prokuratora (innej strony) w pierwotnym brzmieniu art. 404 § 2 k.p.k., dokonał jego nowelizacji, $\mathrm{w}$ ramach której uniezależniono prowadzenie rozprawy odroczonej w dalszym ciągu od woli stron, wykluczając jedynie jej kontynuowanie w wypadku zmiany składu sądu. Choć niewątpliwie wyeliminowanie sprzeciwu między innymi prokuratora w omawianej kwestii pozwala na dalej idące odstępstwa od zasady koncentracji materiału procesowego, to jednak z pragmatycznego punktu widzenia ruch ten został w doktrynie oceniony jako trafny ${ }^{43}$.

W zakresie instytucji wydania wyroku skazującego bez przeprowadzania postępowania dowodowego (art. $387 \S 2$ k.p.k.) sprzeciw prokuratora ma to znaczenie, że blokuje możliwość uwzględnienia wniosku oskarżonego i zakończenia postępowania wydaniem wyroku skazującego o określonej i, co istotne, wnioskowanej przez oskarżonego treści, a w konsekwencji prowadzi do konieczności przeprowadzenia postępowania dowodowego w trakcie rozprawy. Jak już wspominano wcześniej, wprowadzenie do art. 387 § 2 k.p.k. konstrukcji sprzeciwu prokuratora było wynikiem krytycznych uwag dotyczących funkcjonującej dotąd konstrukcji zgody stron, w tym prokuratora, a co za tym idzie, miało na celu usprawnienie procedowania $\mathrm{w}$ ramach instytucji, do której odnosi się ów

${ }^{42}$ Kodeks postępowania karnego, t. 2. Komentarz... (komentarz do art. 404 k.p.k.).

43 Ibidem. 
sprzeciw. Z kolei ratio legis funkcjonowania sprzeciwu prokuratora o charakterze blokującym możliwość wydania orzeczenia przez sąd wynika z faktu, że to prokurator, który w postępowaniu sądowym uzyskuje status oskarżyciela, jest dysponentem skargi publicznej. Posiadanie przez niego prawa do sprzeciwienia się wydaniu wyroku skazującego na warunkach proponowanych przez oskarżonego daje mu zaś możliwość przedstawienia dowodów i argumentów na poparcie odmiennego od przedstawionego przez oskarżonego stanowiska dotyczącego rodzaju i rozmiaru konsekwencji karnoprawnych zarzucanego mu przestępstwa. W tym zakresie wprowadzona do art. $387 \S 2$ k.p.k. konstrukcja sprzeciwu, choć blokuje możliwość wydania wyroku w sprawie, to jednak uniemożliwia jedynie szybsze zakończenie postępowania, skutkując koniecznością przeprowadzenia postępowania dowodowego w czasie rozprawy, co jest zasadą i nie przesądza o ostatecznej treści orzeczenia wydanego przez sąd w danej sprawie. Podobne uwagi należy wysunąć w stosunku do konstrukcji sprzeciwu prokuratora w instytucji wniosku oskarżonego o skazanie go bez przeprowadzania rozprawy (art. 338a k.p.k. w związku z art. 343a $\S 2$ k.p.k.). W tym zakresie sprzeciw prokuratora wobec uwzględnienia wniosku oskarżonego blokuje jedynie możliwość szybszego procedowania i wydania wyroku w sprawie. Wyrażenie przez prokuratora sprzeciwu prowadzi do konieczności wyznaczenia rozprawy i przeprowadzenia postępowania dowodowego (chyba że oskarżony złoży wniosek w trybie art. $387 \S 2$ k.p.k., a prokurator nie zgłosi w tej sytuacji sprzeciwu). Nie przesądza też treści ostatecznego orzeczenia sądu w sprawie.

Powyżej omówione przypadku wykorzystania konstrukcji sprzeciwiania się prokuratora w poszczególnych instytucjach procesu karnego istotnie blokują określony sposób procedowania i/lub wydanie określonej treści orzeczenia. Nie determinują jednak ani odmiennego od podstawowych i przewidzianych w przepisach k.p.k. zasad sposobu procedowania w danej sprawie, ani też treści orzeczenia sądu. Sprzeciw prokuratora wymusza bowiem przeprowadzenia postępowania na zasadach ogólnych, uniemożliwiając wydanie orzeczenia o postulowanej przez oskarżonego treści. Sąd po zrealizowaniu postępowania dowodowego w trakcie rozprawy ma swobodę w kształtowaniu treści orzeczenia, w tym takiej, o którą uprzednio wnioskował oskarżony, a której sprzeciwił się prokurator, jako trafnej w świetle całokształtu ujawnionych podczas rozprawy okoliczności (art. 410 k.p.k.).

\section{VIII}

W 2016 roku ustawodawca postanowił wykorzystać znaną z procesu karnego konstrukcję sprzeciwiania się prokuratora $\mathrm{w}$ innych instytucjach postępowania karnego. Po pierwsze, konstrukcja sprzeciwu prokuratora pojawiła się 
$\mathrm{w}$ instytucji jawności rozprawy głównej w jej aspekcie zewnętrznym ${ }^{44}$. Przepis art. $360 \S 2$ k.p.k. stanowi, że jeżeli prokurator sprzeciwi się wyłączeniu jawności, rozprawa ma charakter jawny. Dotyczy to opisanych w art. $360 \S 1$ k.p.k. przypadków wyłączenia jawności rozprawy głównej na wniosek. Trzeba w tym miejscu przypomnieć, że jawność rozprawy głównej jest wartością o charakterze konstytucyjnym. Wedle przytaczanego już wcześniej art. 45 ust. 1 Konstytucji Rzeczypospolitej Polskiej każdy ma prawo do sprawiedliwego i jawnego (podkr. K.J.L.) rozpatrzenia sprawy bez nieuzasadnionej zwłoki przez właściwy, niezależny, bezstronny i niezawisły sąd. Oczywiście wzgląd na inne wartości, w tym te o charakterze konstytucyjnym, czy też negatywne skutki jawności procesu uzasadniają ograniczenie zasady jawności rozprawy głównej na rzecz jej utajnienia przed społeczeństwem. W szczególności można tu wskazać na pewne zagrożenia wynikające $\mathrm{z}$ jawnego rozpoznawania sprawy, $\mathrm{w}$ tym ujawnienie faktów objętych tajemnicą czy dotyczących sfery życia prywatnego uczestników postępowania, trwałe napiętnowanie oskarżonego, problemy $\mathrm{z}$ readaptacją społeczną skazanego, ujawnienie niepożądanych sposobów popełniania przestępstw. Wobec tego przyjęcie bezwzględnej zasady jawności rozpoznania sprawy przed sądem nie jest możliwe. Tymczasem na mocy art. $360 \S 2$ k.p.k. prokurator uzyskał prawo do wyrażania sprzeciwu wobec utajnienia rozprawy na wniosek strony, na przykład oskarżonego, który został należycie umotywowany i dostatecznie wykazuje istnienie jednej z przewidzianych w art. $360 \S 1$ k.p.k. podstaw uzasadnienia wyłączenia jawności rozprawy sądowej. Co więcej, choć wniosek taki rozpoznaje sąd, przed którym toczy się postępowanie, badając istnienie i zasadność utajnienia przebiegu procesu przed publicznością, to sprzeciw prokuratora przesądza o treści sędziowskiego rozstrzygnięcia w sprawie złożonego wniosku. Trzeba przy tym zauważyć, że ów sprzeciw determinuje treść rozstrzygnięcia sądu o wniosku niezależnie od jego zasadności, bez konieczności uzasadnienia samego sprzeciwu. Nie chodzi tu zatem o klasyczne zajęcie stanowiska przez prokuratora (działającego jako oskarżyciel na etapie postępowania jurysdykcyjnego) w przedmiocie wniosku drugiej strony, które będzie rozważane przez sąd w toku narady nad rozstrzygnięciem. Analizując wprowadzenie sprzeciwu prokuratora w odniesieniu do jawności rozprawy sądowej, należy przypomnieć, że to sąd jest „gospodarzem” postępowania jurysdykcyjnego. Zgodnie z art. $366 \S 1$ k.p.k. przewodniczący składu orzekającego kieruje rozprawą i czuwa nad jej prawidłowym przebiegiem, bacząc przy tym, aby zostały wyjaśnione wszystkie istotne okoliczności sprawy. Oznacza to, że to sąd, prowadząc rozprawę, bierze jednocześnie odpowiedzialność za jej przebieg, w tym za zakres informacji o nim, które mają

44 Jawność procesu karnego na etapie jurysdykcyjnym w aspekcie zewnętrznym dotyczy możliwości obserwowania postępowania przez społeczeństwo i uzyskania informacji o jego przebiegu. Obok jawności zewnętrznej wyróżnia się nadto jawność wewnętrzną procesu karnego przed sądem, która odnosi się z kolei do stron procesu i ma charakter bezwzględny — szerzej zob. S. Waltoś, P. Hofmański, op.cit., s. 215, 218 oraz 317 n. 
zostać udostępnione publiczności (społeczeństwu) i rozważa przy tym kolidujące ze sobą wartości ${ }^{45}$. Sprzeciw prokuratora w zakresie wniosku o wyłączenie jawności wyznacza sądowi w sposób władczy sposób prowadzenia postępowania (to jest w trybie jawnym), co może być wykorzystane przeciwko sądzonej jednostce, umożliwiając celowe ujawnianie społeczeństwu określonych faktów, które mogą na przykład naruszyć ważny prywatny interes oskarżonego.

Po drugie, ustawodawca wydłużył do zamknięcia przewodu sądowego na pierwszej rozprawie głównej termin złożenia przez pokrzywdzonego oświadczenia o cofnięciu wniosku o ściganie za przestępstwo publicznoskargowe z oskarżenia publicznego, a jednocześnie rozszerzył skuteczność sprzeciwu prokuratora w odniesieniu do tego oświadczenia, przyznając mu decydujący głos w kwestii skuteczności cofnięcia wniosku o ściganie także po rozpoczęciu przewodu sądowego (art. $12 \S 3$ k.p.k.). Skutkiem wyrażenia przez prokuratora sprzeciwu jest konieczność przeprowadzenia przez sąd postępowania. Tak szeroko ujęte pod względem temporalnym prawo prokuratora do sprzeciwienia się cofnięciu wniosku o ściganie ingeruje w nieuzasadniony sposób w proces sądowy, a ściślej, w jego zasadność i konieczność. Proces karny uwzględnia bowiem szereg wartości, które wymagają rozważania. Problem jednak w tym, że na etapie postępowania jurysdykcyjnego organem do tego właściwym jest sąd, który powinien rozstrzygnąć konflikt wartości stojących z jednej strony za ściganiem, a z drugiej za zaniechaniem ścigania, co znajduje wyraz $\mathrm{w}$ treści orzeczenia $\mathrm{w}$ przedmiocie oświadczenia pokrzywdzonego o cofnięciu ścigania. W omawianym przypadku konstrukcja sprzeciwienia się także nie przewiduje jakiegokolwiek uzasadnienia wyrażenia przez prokuratora sprzeciwu, z pominięciem rozważenia kolidujących wartości leżących u podstaw instytucji cofnięcia wniosku o ściganie, a przez to staje się wysoce uznaniowa ${ }^{46}$. Dowolna i instrumentalnie potraktowana decyzja prokuratora o sprzeciwieniu się cofnięciu ścigania może zaś prowadzić do nieuzasadnionego kontynuowania postępowania wobec oskarżonego, poddając go rygorom procesowym w sytuacji, gdy taki proces i jego rygory w okolicznościach sprawy jawią się w oczywisty sposób jako nieuzasadnione i bezcelowe.

Po trzecie, dzięki konstrukcji sprzeciwiania się prokurator uzyskał decydujący wpływ na wykonalność nieprawomocnego postanowienia sądu o dalszym stosowaniu tymczasowego aresztowania, z zastrzeżeniem dotyczącym zamiany tymczasowego aresztowania na poręczenie majątkowe (art. 257 § 2 k.p.k.), że środek ten ulegnie zmianie pod warunkiem złożenia — nie później niż w wyznaczonym terminie - określonego poręczenia majątkowego. Po raz kolejny $\mathrm{w}$ toku postępowania jurysdykcyjnego prokurator, wysuwając sprzeciw, decyduje o biegu procesu w sposób odmienny od modelowego ujęcia, przy czym skutek

45 Zob. W. Jasiński, [w:] Kodeks postępowania karnego. Komentarz, pod red. J. Skorupki, Warszawa 2021, s. 990.

${ }^{46}$ K. Gajowniczek-Pruszyńska, P. Karlik, Kodeks postępowania karnego. Komentarz do ustawy z 19.7.2019 r., Warszawa 2020 (komentarz do art. 12 k.p.k.). 
złożonego sprzeciwu nie znajduje uzasadnienia. Wszak to sąd jako jedyny konstytucyjnie uprawniony organ decyduje o pozbawieniu jednostki wolności osobistej. $Z$ uwagi na konstrukcję podstaw i przesłanek tymczasowego aresztowania decyzja $\mathrm{w}$ przedmiocie dalszego pozbawiania wolności oskarżonego powinna pozostawać w wyłącznej kompetencji sądu. Tymczasem to prokurator poprzez wyrażenie sprzeciwu rozstrzyga o tym, że podsądny, mimo zaistnienia przesłanek uzasadniających uchylenie aresztu po spełnieniu warunku wpłaty poręczenia majątkowego, nie opuści aresztu śledczego. W rezultacie prokurator swoją postawą może doprowadzić do nieuzasadnionego przedłużania okresu pozbawienia wolności oskarżonego.

Po czwarte, wśród najnowszych zmian w obrębie k.p.k. znalazło się wprowadzenie konstrukcji sprzeciwu prokuratora do instytucji listu żelaznego. W ramach procedury w przedmiocie jego wydania decyzję podejmuje sąd okręgowy, rozważając wniosek pod kątem ustawowo określonych przesłanek. Jednak zgodnie $\mathrm{z}$ aktualnie obowiązującym przepisem art. $281 \S 2$ k.p.k. w trakcie postępowania przygotowawczego list żelazny może być wydany na wniosek prokuratora albo przy braku jego sprzeciwu. Jeśli prokurator wyrazi taki sprzeciw, to decyduje on w istocie o treści orzeczenia sądu rozpoznającego wniosek o wydanie listu żelaznego. I tu także decyzja oskarżyciela ma charakter uznaniowy, bowiem nie musi ona zawierać żadnego uzasadnienia. W ten sposób uzyskuje on wpływ nie tylko na decyzję sądu, ale także na dalszy bieg postepowania, powodując na przykład utratę istotnego w sprawie źródła dowodowego, czyli oskarżonego, który w ogóle nie złożyłby wyjaśnień, nie uzyskawszy listu żelaznego.

\section{IX}

Nie ulega wątpliwości, że oprócz zagadnień ustrojowych również aspekt procesowy $\mathrm{w}$ zasadniczej mierze determinuje prawidłowość realizacji przez sąd funkcji sądzenia. $Z$ jednej bowiem strony niezawisłość sędziego i niezależność sądów oraz gwarancje tych przymiotów władzy sądowniczej i osób, którym one przysługują, z drugiej zaś strony model procesu karnego i szczegółowe rozwiązania poszczególnych instytucji karnoprocesowych przekładają się na sposób sprawowania wymiaru sprawiedliwości karnej.

W kontekście zasady podziału władz oraz powierzenia wymiaru sprawiedliwości sądom (i trybunałom) w ramach odrębnej władzy instytucje te i pracujący w nich sędziowie mają i wykonują władzę. Wskazać trzeba, że w kontekście historycznym chodziło właśnie o władzę sędziego. $Z$ tego powodu konieczne jest krótkie przypomnienie genezy zasady trójpodziału władzy. Od XVIII wieku formułowano postulaty ograniczenia sędziowskiej władzy w związku z wykonywaniem państwowego prawa do karania przez zależnych od władzy wykonawczej sędziów. Jednakowoż trzeba podkreślić kierunek owego ograniczania władzy sędziego. Najlepiej widać to w poglądach francuskich encyklopedystów, którzy 
postulowali odebranie sędziemu możliwości tworzenia w drodze analogii lub na podstawie zwyczaju nowych stanów faktycznych oraz oderwanie władzy sądowniczej od władzy wykonawczej, która wykorzystywała sądy w celu ucisku obywateli ${ }^{47}$. Spełnieniem tych postulatów było $z$ jednej strony wprowadzenie zasady podziału władz $\mathrm{z}$ jednoczesnym ich równoważeniem się $\mathrm{w}$ kierunku wzajemnego ich ograniczania się oraz - z drugiej strony — związanie sędziego tekstem ustawy. Propozycje te były związane z prymatem praw jednostki i ich ochroną. Doświadczenia z czasów III Rzeszy, kiedy to prawo karne było stosowane, ściśle przestrzegane i instrumentalnie traktowane jako forma realizacji określonej polityki karnej spowodowały rewizję poglądów w tym zakresie, czego rezultatem była między innymi sformułowana przez Gustava Radbrucha koncepcja tak zwanego ustawowego bezprawia i ponadustawowego prawa ${ }^{48}$. Stąd też o ile w demokratycznym państwie prawnym zasada trójpodziału i wzajemnego równoważenia się władz nadal stanowi regułę ustrojową, o tyle nie do przyjęcia jest traktowanie władzy sądowniczej i sprawowanego w ramach tej władzy wymiaru sprawiedliwości karnej jako prostej i sztywnej formy realizacji ustaw, których tekst stanowi granicę tejże władzy, a tak zdaje się postrzegać tworzenie prawa obecny ustawodawca. Wyrazem tego jest wprowadzanie zmian, które formalnie obowiązują jako element normujący proces karny, a jednocześnie umożliwiają wpływanie na jego bieg oraz treść podejmowanych w jego toku decyzji. W rezultacie przebieg procesu karnego ulega stopniowej kontroli podmiotów pozasądowych, w szczególności tych, które reprezentują władzę wykonawczą (prokurator). Taki zaś kierunek zmian otwiera pytanie, czy proces karny ulega autorytaryzacji, to znaczy przyjmuje cechy autorytarnej regulacji prawnej.

Poszukując sposobu na odwrócenie tego kierunku zmian legislacyjnych, warto podkreślić, że istotą trzeciej władzy, na kontroli której tak zależy pozostałym władzom (ustawodawczej za pomocą stanowienia określonych przepisów procesowych i wykonawczej poprzez realizacji uchwalonych przepisów przez prokuratora w danym postępowaniu), są wykładnia i stosowanie prawa. Wszak to sędzia jest wyłącznie uprawniony do interpretacji (wykładni) przepisów prawnych (uchwalonych i wykonywanych) w celu ustalenia treści normy prawnej, która następnie będzie podstawą wiążącego rozstrzygnięcia sądowego w jednostkowej sprawie na zasadzie niezależności orzekającej osoby i ustrojowej odrębności sądu (stosowanie prawa ${ }^{49}$. W tym zaś zakresie jedynym warunkiem prawidłowej wykładni i jednocześnie elementem legitymizującym jej wynik jest powszechne

${ }^{47}$ R. Lemkin, Sędzia w obliczu nowoczesnego prawa karnego i kryminologji, Warszawa 1933, s. 13.

48 Zob. G. Radbruch, Ustawowe bezprawie i ponadustawowe prawo, [w:] idem, Filozofia prawa, przeł. E. Nowak, Warszawa 2009, s. 244-254.

49 Znaczenie tej władzy sędziowskiej podkreślają już we wstępie swojego opracowania J. Gutowski i P. Kardas, Wyktadnia i stosowanie prawa w procesie opartym na Konstytucji, Warszawa 2017, s. 4. 
przyjęcie i akceptacja jej reguł ${ }^{50}$. Jednocześnie trzeba podkreślić, że to właśnie sędzia (sąd) jest gwarantem prawidłowej wykładni i stosowania prawa.

W konsekwencji w opartym na zasadzie trójpodziału władz demokratycznym państwie prawnym sądy stają się gwarantem praw i wolności jednostki. Podejmując rozstrzygnięcie w jednostkowej sprawie, niewątpliwie określają one sytuację prawną obywatela, w tym zakres jego praw i wolności. Owo rozstrzygnięcie odbywa się także w określonej procedurze. Potrzeba gwarancji ochrony praw i wolności jest szczególnie widoczna w gałęziach prawa represyjnego, gdzie określenie granic ingerencji państwa w prawa i wolności człowieka nabiera szczególnego znaczenia, nie tylko w zakresie treści orzeczenia sędziowskiego, ale i w równym stopniu właśnie w odniesieniu do procedury zmierzającej do jego wydania.

Ujmując władzę sądu i jego rolę w przedstawiony powyżej sposób, trzeba wskazać, że wprowadzone do postępowania karnego konstrukcje sprzeciwu, mające wpływ na określony sposób procedowania przez sąd lub treść wydawanych przez niego rozstrzygnięć, można zinterpretować tak, by zachować decydujący wpływ sądu na postępowanie jurysdykcyjne i wydawane orzeczenia w jego toku. W odniesieniu do skutków sprzeciwu prokuratora w zakresie decyzji sądu o przedłużeniu tymczasowego aresztowania $\mathrm{z}$ zastrzeżeniem jego zamiany na poręczenie majątkowe (art. $257 \S 2$ k.p.k.) trafnie dostrzeżono w literaturze, że wstrzymanie wykonania postanowienia może dotyczyć jedynie takich orzeczeń, które zawierają rozstrzygnięcia nadające się do wstrzymania. Nie można więc wstrzymać wykonania decyzji o areszcie warunkowym, gdyż byłoby to równoznaczne $\mathrm{z}$ dalszym stosowaniem tymczasowego aresztowania, pomimo że ustało ono ex lege z chwilą złożenia poręczenia majątkowego. Sprzeciw prokuratora nie może zatem spowodować wstrzymania (odroczenia w czasie) zamiany tymczasowego aresztowania na poręczenie majątkowe, gdyż skutek ten wynika $\mathrm{z}$ ustawy ${ }^{51}$. Z kolei w odniesieniu do sprzeciwu prokuratora $\mathrm{w}$ procedurze wydawania listu żelaznego w doktrynie podniesiono, że zmieniony przepis art. $281 \S 2$ k.p.k. należy interpretować z zastosowaniem reguł wykładni systemowej. Należy przyjąć, że organem podejmującym decyzję w tej kwestii jest sąd, a stronom zainteresowanym, to jest oskarżonemu i prokuratorowi, przysługują takie same uprawnienia i środki prawne do obrony własnego stanowiska oraz zwalczania stanowiska przeciwnika. Sprzeciw prokuratora stanowi zatem wyraz negatywnej oceny wniosku osoby sądzonej i postulat, aby sąd nie uwzględnił go i nie wydał listu żelaznego ${ }^{52}$. Podobnie należy ocenić charakter i skutki sprzeciwu prokuratora przy ocenie przez sąd oświadczenia pokrzywdzonego o cofnięciu wniosku

50 Na szeroki zakres dyskrecjonalnej władzy sędziego i jednocześnie wagę stosowania odpowiednich reguł wykładni przy jej realizacji wskazuje B. Wojciechowski, Wyważanie reguł wykładni jako element dyskrecjonalności sędziowskiej, [w:] W poszukiwaniu dobra wspólnego. Księga jubileuszowa profesora Macieja Zielińskiego, red. A. Chodun, S. Czepita, Szczecin 2010, s. 165-173.

51 Zob. J. Skorupka, [w:] Kodeks postepowania karnego..., s. 635.

52 Zob. ibidem, s. 716. 
o ściganie złożonego podczas rozprawy oraz przy rozpoznawaniu przez sąd wniosku o wyłączenie jawności w trybie art. 360 § 1 k.p.k.

\section{Bibliografia}

Bankowicz M., Autorytaryzm i totalitaryzm - analiza porównawcza, [w:] Totalitaryzmy XX wieku. Idee, instytucje, interpretacje, red. W. Kozub-Ciembroniewicz, Kraków 2010.

Bodnar A., Polska to już kraj konkurencyjnego autorytaryzmu. Obudźmy się - wykład RPO Adama Bodnara w Klubie Staromiejskim, Biuro Rzecznika Praw Obywatelskich, 20 kwietnia 2021 roku, https://www.rpo.gov.pl/pl/content/polska-konkurencyjny-autorytaryzm-obudzmy-sie-wy klad-rpo-adama-bodnara.

Bosiacki A., Pomiędzy państwem prawnym a autorytaryzmem. Z polskich rozważań nad poszukiwaniem optymalnego ustroju państwa po odzyskaniu niepodległości w III Rzeczypospolitej, „Studia nad Autorytaryzmem i Totalitaryzmem” 38, 2016, nr 4.

Gajowniczek-Pruszyńska K., Karlik P., Kodeks postępowania karnego. Komentarz do ustawy z 19.7.2019 r., Warszawa 2020.

Gdula M., Nowy autorytaryzm, Warszawa 2018.

Gutowski J., Kardas P., Wyktadnia i stosowanie prawa w procesie opartym na Konstytucji, Warszawa 2017.

Jasiński W., Nielegalnie uzyskane dowody w procesie karnym. W poszukiwaniu optymalnego rozwiązania, Warszawa 2019.

Kodeks postępowania karnego. Komentarz, red. J. Skorupka, Warszawa 2021.

Kodeks postęowania karnego, t. 2, Komentarz do artykułów 297-467, red. P. Hofmański, Warszawa 2011.

Koncewicz T.T., Sprawiedliwość proceduralna w sądach unijnych. Pierwsze kroki, „Palestra” 2010, nr 11-12.

Lemkin R., Sędzia w obliczu nowoczesnego prawa karnego i kryminologji, Warszawa 1933.

Leżak K.J., Sędzia wobec nowego prawa karnego procesowego, [w:] Norma postępowania karnego. Sędzia wobec zmian prawa karnego procesowego, red. J. Skorupka, K.J. Leżak, Kraków 2018.

Linz J.J., Totalitaryzm i autorytaryzm, [w:] Władza i społeczeństwo. Antologia tekstów z zakresu socjologii polityki, wyb. i oprac. J. Szczupaczyński, Warszawa 1995.

Ławnikowicz G., W poszukiwaniu istoty nowego autorytarnego porzadku. Antoniego Peretiatkowicza koncepcja cezaryzmu demokratycznego, „Studia nad Autorytaryzmem i Totalitaryzmem” 42, $2020, \mathrm{nr} 2$.

Proces karny, red. J. Skorupka, Warszawa 2018.

Radbruch G., Ustawowe bezprawie i ponadustawowe prawo, [w:] idem, Filozofia prawa, przeł. E. Nowak, Warszawa 2009.

Rojszczak M., Nieograniczone programy inwigilacji elektronicznej a koncepcja państwa autorytarnego, „Studia nad Autorytaryzmem i Totalitaryzmem” 42, 2020, nr 2.

Rzetelny proces karny $w$ orzecznictwie sądów polskich i międzynarodowych, red. P. Wiliński, Warszawa 2009.

Tomasiewicz J., Naprawa czy zniszczenie demokracji? Tendencje autorytarne i profaszystowskie w polskiej myśli politycznej 1921-1935, Katowice 2012.

Waltoś S., Hofmański P., Proces karny. Zarys systemu, Warszawa 2018.

Wojciechowski B., Wyważanie regut wyktadni jako element dyskrecjonalności sędziowskiej, [w:] W poszukiwaniu dobra wspólnego. Księga jubileuszowa profesora Macieja Zielińskiego, red.

A. Chodun, S. Czepita, Szczecin 2010.

Ziembiński Z., Szkice z metodologii szczegółowych nauk prawnych, Warszawa-Poznań 1983. 